University of Nebraska - Lincoln DigitalCommons@University of Nebraska - Lincoln

2014

\title{
Molecular characterization of antibiotic resistant Salmonella Typhimurium and Salmonella Kentucky isolated from pre- and post-chill whole broilers carcasses
}

\author{
Tagelsir Mohamed \\ University of Maryland Eastern Shore \\ Shaohua Zhao \\ U.S. Food and Drug Administration \\ David G. White \\ U.S. Food and Drug Administration \\ Salina Parveen \\ University of Maryland Eastern Shore, sparveen@umes.edu
}

Follow this and additional works at: http://digitalcommons.unl.edu/publichealthresources

Mohamed, Tagelsir; Zhao, Shaohua; White, David G.; and Parveen, Salina, "Molecular characterization of antibiotic resistant Salmonella Typhimurium and Salmonella Kentucky isolated from pre- and post-chill whole broilers carcasses" (2014). Public Health Resources. 298.

http://digitalcommons.unl.edu/publichealthresources/298 


\title{
Molecular characterization of antibiotic resistant Salmonella Typhimurium and Salmonella Kentucky isolated from pre- and post-chill whole broilers carcasses
}

\author{
Tagelsir Mohamed ${ }^{\mathrm{a}}$, Shaohua Zhao ${ }^{\mathrm{b}}$, David G. White ${ }^{\mathrm{b}}$, Salina Parveen ${ }^{\mathrm{a}, *}$ \\ ${ }^{a}$ Food Science and Technology Ph.D. Program, Department of Agriculture, Food and Resource Sciences, 2116 Center for Food Science and Technology, \\ University of Maryland Eastern Shore, Princess Anne, MD 21863, USA \\ ${ }^{\mathrm{b}}$ Division of Animal and Food Microbiology, Office of Research, Center for Veterinary Medicine, U.S. Food and Drug Administration, Laurel, MD 20708, USA
}

\section{A R T I C L E I N F O}

\section{Article history:}

Received 7 November 2012

Received in revised form

2 August 2013

Accepted 10 August 2013

Available online 22 August 2013

\section{Keywords:}

Salmonella Typhimurium

Salmonella Kentucky

Pre- and post-chill

Pulsed-field gel electrophoresis

Virulence factors

\begin{abstract}
A B S T R A C T
There is conflicting data regarding whether commercial chilling has any effect on persistence of Salmonella serovars, including antibiotic resistant variants, on chicken carcasses. A total of 309 Salmonella Typhimurium and Salmonella Kentucky isolates recovered from pre- and post-chill whole broiler carcasses were characterized for genetic relatedness using Pulsed Field Gel Electrophoresis (PFGE) and for the presence of virulence factors (invA, $p a g C, s p v C$ ) by PCR and for aerobactin and colicin production by bioassays. A subset of these isolates $(n=218)$ displaying resistance to either sulfisoxazole and/or ceftiofur [S. Typhimurium $(n=66)$ and $S$. Kentucky $(n=152)$ ] were further tested for the presence of associated antibiotic resistance elements (class-I integrons and bla $\mathrm{CMY}_{\mathrm{CM}}$ genes) by PCR. All 145 ceftiofur resistant $S$. Kentucky and $S$. Typhimurium isolates possessed bla $a_{\mathrm{CMY}}$ genes. Class-I integrons were only detected in $6.1 \%(n=4 / 66)$ of sulfisoxazole resistant $S$. Typhimurium isolates. The PFGE analysis revealed the presence of genetically diverse populations within the recovered isolates but clusters were generally concordant with serotypes and antimicrobial resistance profiles. At a $100 \%$ pattern similarity index, thirty-six percent of the undistinguishable $S$. Typhimurium and $22 \%$ of the undistinguishable $S$. Kentucky isolates were recovered from the same chilling step. All isolates possessed the invA and pagC genes, but only $1.4 \%$ possessed $s p v C$. Irrespective of the chilling step, there was a significant difference $(P<0.05)$ in the production of aerobactin and colicin between $S$. Typhimurium and $S$. Kentucky isolates. Taken together, these results indicate that chilling impacted the recovery of particular Salmonella clonal groups but had no effect on the presence of class-I integrons, bla $a_{\mathrm{CMY}}$ genes, and tested virulence factors.
\end{abstract}

(c) 2013 Elsevier Ltd. All rights reserved.

\section{Introduction}

Salmonellosis is a worldwide health problem and Salmonella infections are the second leading cause of bacterial food-borne illness in the United States, causing an estimated one million cases of salmonellosis, 19,336 hospitalizations, and 378 fatalities per year (Scallan et al., 2011). Approximately 3-10\% results in bacteremia requiring treatment with antibiotics (Mead et al., 1999). Food of animal origin, especially poultry and poultry products, has been implicated in outbreaks of human salmonellosis (Zivkovic et al., 1997). Antibiotic resistance increases the mortality rates due to food-borne illness (Helms et al., 2002) and has been linked to overuse or misuse of antibiotics (WHO, 2000).

\footnotetext{
* Corresponding author. Tel.: +1 410651 8339; fax: +1 4106518498.

E-mail address: sparveen@umes.edu (S. Parveen).
}

Many antibiotic resistant Gram-negative bacteria contain integrons, which are genetic elements that mediate drug resistance. The use of a single antibiotic as treatment can also select for resistance to other antibiotics whose genes reside in the same integrons (Arestrup et al., 2001). Five classes of integrons have been described among clinical bacterial isolates. Class-I integrons have been shown to be the most prevalent in clinical isolates of the family Enterobacteriaceae and these integrons can be found within transposons, the chromosome and/or plasmids (Brown et al., 1996; Fluit, and Schmitz, 2004).

Cephalosporins are structurally and pharmacologically related to the penicillins, and have a beta-lactam ring structure that interferes with synthesis of the bacterial cell wall that protects them. Cephalosporins disrupt the synthesis of the peptidoglycan layer of bacterial cell walls, which causes the walls to break down and eventually the bacteria die. Cephalosporins are important drugs to treat bacterial infections. First generation cephalosporins are 
Table 1

Salmonella Typhimurium and $S$. Kentucky isolates tested for the presence of class-I integrons and $b l a_{\mathrm{CMY}}$ genes.

\begin{tabular}{|c|c|c|c|c|c|c|}
\hline \multirow[t]{2}{*}{ Gene } & \multicolumn{2}{|l|}{ Sulfisoxazole-resistant } & \multicolumn{2}{|l|}{ Ceftiofur-resistant } & \multicolumn{2}{|l|}{ Both resistant } \\
\hline & Typhimurium $(n=20)$ & Kentucky $(n=2)$ & Typhimurium $(n=2)$ & Kentucky $(n=143)$ & Typhimurium $(n=44)$ & Kentucky $(n=7)$ \\
\hline Integrons & 4 & 0 & 0 & 0 & 0 & 0 \\
\hline$b l a_{\mathrm{CMY}}$ & 0 & 0 & 2 & 143 & 44 & 7 \\
\hline Both & 0 & 0 & 0 & 0 & 0 & 0 \\
\hline Total & 4 & 0 & 2 & 143 & 44 & 7 \\
\hline
\end{tabular}

Thirty nine pre- and 27 post-chill $S$. Typhimurium isolates; 77 pre- and 75 post-chill $S$. Kentucky.

moderate spectrum agents, they are predominantly active against gram-positive bacteria, and successive generations have increased activity against gram-negative bacteria. The second generation cephalosporins have a greater gram-negative spectrum while retaining some activity against gram-positive bacteria. They are also more resistant to beta-lactamase. Third generation cephalosporins have a broad spectrum of activity and further increased activity against gram-negative organisms. Some members of this group have decreased activity against gram-positive organisms (Beers, 2003).

Ceftiofur is a third generation cephalosporin, approved for systemic use in food animals in the U. S. (Bradford et al., 1999). The bla $a_{\mathrm{CMY}}$ genes encoding a cephalomycinase have been associated with decreased susceptibility to first, second and third generation cephalosporins, including ceftiofur and ceftriaxone (Zhao et al., 2001). This situation highlights the importance of determining the antibiotic resistance associated genes.

Studies have demonstrated that chill water and the chilling process can be a significant source of pathogen contamination between carcasses (Izat et al., 1989). Studies have also demonstrated that other procedures used during the first and second processing in the poultry plants may also contribute to cross contamination between carcasses (Beery et al., 1988). A number of investigators have suggested that processing conditions may play a significant role in promoting the selection of antimicrobial resistant pathogens during processing (Logue et al., 2003; Noorwood and Gilmour, 2000). Previously, Parveen et al. (2007) investigated the prevalence of Salmonella serotypes recovered from pre- and postchill whole broiler carcasses. The predominant serotypes for preand post-chill carcasses were Salmonella Kentucky and Salmonella Typhimurium, and $80 \%$ of isolates were resistant to at least one antimicrobial and 50\% were resistant to three or more antimicrobials (Parveen et al., 2007).

Pulsed Field Gel Electrophoresis (PFGE) analysis is a useful tool for studying the persistence and dissemination of Salmonella due to its high discriminatory ability and reproducibility. Several investigators (Xia et al., 2009; Zhao et al., 2003) have used PFGE to assess genetic relatedness among the Salmonella serotypes recovered from humans, sick food animals, and a variety of foods.

The outcome of a Salmonella infection mainly depends on the status of the host and the bacterium. The status of the bacterium is determined by the presence or absence of the genes for various virulence factors in the bacteria, and whether these factors are expressed in the bacterium before or during the infection. Olah et al. (2005) reported that the invA gene allows Salmonella to invade cells. The pagC virulence gene encodes an outer membrane protein that promotes survival within macrophages. The $s p v C$ gene promotes prolific growth of salmonellae in host reticuloendothelial tissues. Aerobactin is a siderophore commonly associated with gram negative bacteria, and is a member of the group of hydroxamate siderophores. Aerobactin promotes virulence by enabling the bacteria to sequester iron in iron poor environments like the urinary tract. All colicins are bacteriocins that are produced by some gram negative organisms. Colicin can be bactericidal or bacteriostatic and are composed of three globular protein domains.

However, little research has been conducted on the characterization of antibiotic-resistant Salmonella isolated from pre- and post-chill processed chicken. Thus, there is a need to characterize antibiotic resistant Salmonella isolated from pre- and post-chill processed chicken to determine potential effects of chilling on the persistence of Salmonella subtypes on the carcasses of chicken. The objectives of this study were to determine whether chilling had any effect on the antibiotic resistance genes, PFGE patterns and virulence properties of $S$. Typhimurium and $S$. Kentucky recovered from pre- and post-chill carcasses.

\section{Materials and methods}

\subsection{Salmonella isolates}

The isolates used in this study were collected monthly from preand post-chill whole broiler carcasses from a large poultry plant from July 2004 to June 2005. During each visit, a total of 20 pre- and post-chill carcasses were collected and carcasses were originated from a single farm or producers. Pre- and post-chill isolates were recovered from pre- and post-chill carcasses, respectively (Parveen et al., 2007). A total of 309 S. Typhimurium ( $n=44$ pre-chill; $n=31$ post-chill) and $S$. Kentucky ( $n=102$ pre-chill; $n=132$ post-chill) isolates recovered from whole broiler carcasses were selected for PFGE analysis and detection of virulence associated genes. A subset $(n=218)$ of $S$. Typhimurium $(n=66)$ and $S$. Kentucky $(n=152)$ isolates resistant to sulfisoxazole and/or ceftiofur were tested for class-I integrons and bla $a_{\mathrm{CMY}}$ genes (Table 1 ).

\subsection{Detection of class-I integrons and bla ${ }_{\mathrm{CMY}}$ genes}

For detection of class-I integrons and bla $a_{\mathrm{CMY}}$ genes, DNA was extracted from Salmonella isolates and purified using a DNA purification kit (Boehringer Mannheim, Indianapolis, IN). The presence of bla $_{\mathrm{CMY}}$ genes and class-I integrons were detected by Polymerase Chain Reaction (PCR) assay (Zhao et al., 2003). For each set of bla $a_{\mathrm{CMY}}$ PCR reactions, ceftiofur resistant and susceptible $S$. Typhimurium (CVM1290 and sCVM785) were included as positive and negative controls, respectively. Salmonella enterica serotype Typhimurium DT 104 CVM4011 and Escherichia coli CVM996 were included as positive and negative controls for Class-I integron PCR reactions, respectively. The amplified products were separated by gel electrophoresis in a $1 \%$ agarose gel, stained with ethidium bromide $(40 \mu \mathrm{g} / \mathrm{mL})$ for $20 \mathrm{~min}$ and visualized under UV light.

\subsection{DNA sequencing}

PCR products of class-I integrons and $b l a_{\mathrm{CMY}}$ genes were analyzed on $1 \%$ agarose gel and visualized after ethidium bromide staining. Positive PCR products were purified using exonuclease I/ shrimp alkaline phosphate (Exo-SAP-IT ${ }^{\mathrm{TM}}$ ) (USB Corporation, Cleveland, $\mathrm{OH}$ ), and were sequenced in both directions using the 
Table 2

PCR primers used for amplification of class-I integrons, bla $a_{\mathrm{CMY}}$ genes, invA, pagC, and $s p v C$ Virulence genes.

\begin{tabular}{|c|c|c|c|c|}
\hline Primer & Sequence & $\begin{array}{l}\text { Annealing } \\
\text { Temp }\left({ }^{\circ} \mathrm{C}\right)\end{array}$ & $\begin{array}{l}\text { Amplicon } \\
\text { size (bp) }\end{array}$ & Reference \\
\hline Class-I Integrons & F 5'-GGC ATC CAA GCA GCA AGC-3' R 3'-AAG CAG ACT TGA CCT GAT-5' & 54.0 & 1000 & Zhao et al., 2003 \\
\hline$b^{\prime a} a_{\mathrm{CMY}}$ & F 5'-ATG ATG AAA AAA TCG TTA TG-3' R 3'-TTA TTG TAG CTT TTC AAG AA-5' & 50.0 & 1000 & Zhao et al., 2003 \\
\hline invA & F-GTG-AAT-TAT-CGC-CAC-GTT-CGG; R-TCA-TCG-CAC-CGT-CAA-AGG-AAC & 55.0 & 284 & Rahn et al., 1992 \\
\hline pagC & F-TAT-GAG-GAT-CAC-TCT-CCG-GTA; R-ATT-CTC-CAG-CGG-ATT-CAT-CTA & 55.0 & 318 & Pulkkinen and Miller 1991 \\
\hline spvC & F-TGG-GGC-GGA-AAT-ACC-ATC-TAC-AA; R-GAA-CTG-AGC-GCC-CAG-GCT-AAC-AC & 59.0 & 400 & Suzuki et al., 1994 \\
\hline
\end{tabular}

same PCR primers (Table 2) in $10 \mu$ l reactions, by A; BI 3100 sequencer analyzer (Applied Biosystems, Foster City, CA) and analyzed by searching the GenBank database of the National Center for Biotechnology Information via the Basic Local Alignment Search Tool (BLAST) network service. GenBank Accession numbers DQ861642.1 and GQ398239.1 were used for determining sequence identity of class-I integrons and blaCMY genes, respectively.

\subsection{Pulsed Field Gel Electrophoresis (PFGE)}

Pulsed Field Gel Electrophoresis (PFGE) was performed to generate genomic DNA fingerprinting profiles of $S$. Typhimurium and $S$. Kentucky isolates using Xbal (Boehringer Mannheim, Indianapolis, IN) according to the procedures developed by the Centers for Disease Control and Prevention (CDC) (Gerner-Smidt and Schutz, 2006).

The electrophoresis was performed with CHEF-DR III SYSTEM (Bio-Rad Laboratories, Hercules, CA) using 1\% SeaKem Gold agarose gel in 0.5X Tris-borate-EDTA (TBE) buffer at $14{ }^{\circ} \mathrm{C}$ for $19 \mathrm{~h}$. The electrophoresis conditions were as follows: initial switch time value of $2.16 \mathrm{~s}$, final switch time of $63.8 \mathrm{~s}$ at a gradient of $6 \mathrm{~V} / \mathrm{cm}$ and an included angle of $120^{\circ}$. After electrophoresis the gel was stained with ethidium bromide solution $(40 \mu \mathrm{g} / \mathrm{mL})$ and then de-stained with deionized water. Then DNA bands were visualized with a UV transilluminator and a digital image of PFGE patterns was acquired.

Dendrograms were generated using Bionumerics software (AppliedMaths, Austin, TX). PFGE patterns were established based on the number and arrangement of fragments and computationally based on the levels of relatedness using the Dice similarity coefficient and Unweighted Pair Group Method using arithmetic averages (UPGMA).

\subsection{Detection of virulence genes}

Salmonella isolates were analyzed for virulence genes (invA, $s p v C$, and pagC) by PCR using the methods previously described (Olah et al., 2005). The primer sets used for the genes are listed in Table 2. Amplifications were carried out with $2 \mu$ of DNA template in a $50 \mu \mathrm{l}$ reaction mixture containing deoxynucleotide triphosphates (dATP, dGTP, dCTP, dTTP) at a concentration of $0.25 \mathrm{mM}$ each, $2.5 \mathrm{mM} \mathrm{MgCl}_{2}$, 50 pmol of each primer, $1 \mathrm{U}$ of Gold Taq DNA polymerase (Promega, Madison, WI) and distilled water. The amplification parameters were as follows: denaturation at $94{ }^{\circ} \mathrm{C}$ for $7 \mathrm{~min}\left(5 \mathrm{~min}\right.$ for $s p v \mathrm{C}$ ) then 30 cycles of $94{ }^{\circ} \mathrm{C}$ for one minute, various annealing temperatures (Table 2) for $1.5 \mathrm{~min}$, and $72{ }^{\circ} \mathrm{C}$ for one minute, and a final extension at $72{ }^{\circ} \mathrm{C}$ for $5 \mathrm{~min}$ ( $7 \mathrm{~min}$ for pagC and $s p v C)$. S. Typhimurium strain Lt-2 $\times 3324$ containing a recombinant plasmid with invA (Galan and Curtiss III, 1989), E. coli DH5- $\alpha$ containing a recombinant plasmid with $s p v C$, and $S$. Typhimurium SR $11 \times 3337$ containing a recombinant plasmid with pagC (Gulig et al., 1993) were used as positive controls and Escherichia coli DH5- $\alpha$ (Invitrogen, Carlsbad, CA) was used as negative control for all reactions. Then, PCR products were separated by electrophoresis in a $1 \%$ agarose gel. The gels were stained with ethidium bromide solution $(40 \mu \mathrm{g} / \mathrm{mL})$ for $20 \mathrm{~min}$ and viewed with UV light to determine the presence of the PCR products.

\subsection{Aerobactin assay}

The aerobactin assay developed by Vidotto et al. (1990) was used in this study. Test isolates were stab inoculated into plates of M9 low-iron agar (20 g trypticase soy agar (TSA), $10 \mathrm{~g}$ peptone and $30 \mathrm{~g} \mathrm{NaCl}$, in $1.0 \mathrm{~L}$ of distilled water, $\mathrm{pH} 8.5 \pm 0.2$ containing $200 \mu \mathrm{M}$ of 2, 2'dipyridyl (Sigma Chemical Company, St. Louis, MO) with an iron chelator embedded and E. coli LG 1522 (University of North Dakota) as an indicator microorganism. Inoculated plates were incubated at $37{ }^{\circ} \mathrm{C}$ for $18-24 \mathrm{~h}$. E. coli cannot produce its own aerobactin, but it uses exogenous aerobactin. Growth of $E$. coli LG1522 around the stab sites indicated that the isolate being tested produced aerobactin. E. coli LG1315 (an aerobactin producing strain), and E. coli HB101 ATCC 33694 (which does not produce aerobactin) were used as positive and negative controls, respectively.

\subsection{Colicin assay}

The colicin assay developed by Fredericq (1956) was used in this study. Nutrient agar (Difco, Sparks, MD) was stab inoculated with isolates being tested and two control organisms, E. coli ATCC 23558, a colicin producer, and E. coli ATCC 23559, an organism that cannot produce colicin and is sensitive to colicin. The nutrient agar plates were then incubated at $37^{\circ} \mathrm{C}$ for $18-24 \mathrm{~h}$. The bacterial growth on the plate was then killed with chloroform (Sigma) by inverting the plates over a chloroform-saturated piece of filter paper for $30 \mathrm{~min}$. After killing, half-strength nutrient agar containing E. coli ATCC 23559 (the indicator organism) was poured over the surface of the killed organisms. These plates were then incubated at $37^{\circ} \mathrm{C}$ for $18-$ $24 \mathrm{~h}$. The inability of $E$. coli ATCC 23559 to grow around stab sites was evaluated by examining for zones of growth inhibition around the test colonies. If the growth of the indicator organism was inhibited, then the isolate being tested was considered a colicin producer.

\subsection{Statistical analysis}

A paired $t$-test was used to determine the effect of chilling step on the presence of class-I integrons, bla $a_{\mathrm{CMY}}$ genes, invA, pagC and $s p v C$ genes, PFGE, and the production of aerobactin and colicin bioassays. An alpha level of 0.05 was considered the minimum level for statistical significance. All computations were performed through the Dimension Research Inc. (DRI, Lombard, IL).

\section{Results and discussion}

\subsection{Detection of Class-I integrons and bla ${ }_{C M Y}$ genes}

Chromosomal mutations as well as DNA mobile elements, such as transposons and integrons, have greatly contributed to the rapid 

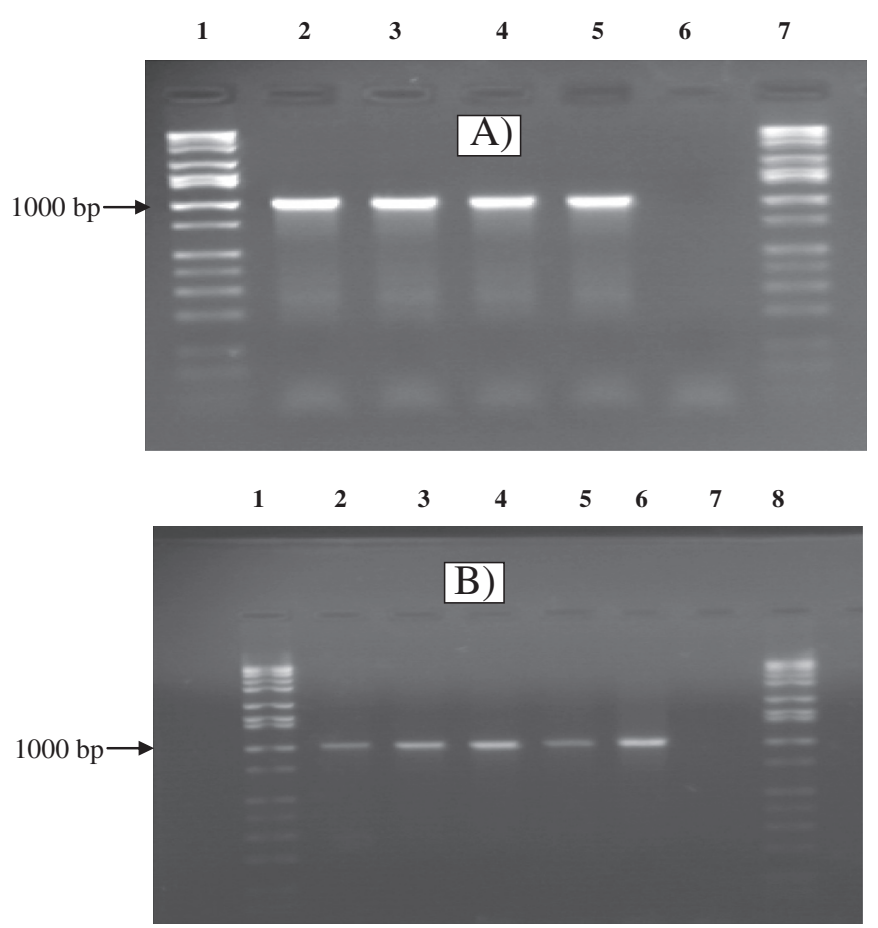

Fig. 1. A) $P C R$ amplification of bla ${ }_{\mathrm{CMY}}$ genes in selected Salmonella Typhimurium and $S$. Kentucky isolates; lanes 1 and 7 Hi Low DNA marker (Minnesota Molecular, Minneapolis, MN); lane 5, positive control; lane 6, negative control; lanes 2 through 4 Salmonella serotypes. Sulfisoxazole and ceftiofur resistant isolates were tested for class-I integrons and bla $a_{\mathrm{CMY}}$ genes, respectively. B) PCR amplification of class-I integrons in selected Salmonella Typhimurium and S. Kentucky isolates; lanes 1 and 8 Hi Low DNA marker (Minnesota Molecular, Minneapolis, MN); lane 6, positive control; lane 7, negative control; lanes 2 through 5 of Salmonella serotypes.

dissemination of antimicrobial resistance (White et al., 2001). Class-I integrons are often associated with sulfisoxazole resistant Salmonella isolates while bla $a_{\mathrm{CM}}$ genes have been associated with ceftiofur resistant Salmonella (White et al., 2001). It has also been reported that increased incidence of Salmonella occurred in prechilled broiler carcasses compared with chilled carcasses (Logue et al., 2003). In this study two predominant Salmonella serotypes (Typhimurium and Kentucky) resistant to sulfisoxazole and/or ceftiofur were tested to study the effect of chilling step and the antibiotic resistance profile on the detection of bla $a_{\mathrm{CMY}}$ genes and class-I integrons. All 145 ceftiofur resistant $S$. Kentucky and $S$. Typhimurium isolates were positive for $b l a_{\mathrm{CMY}}$ Genes. In contrast, class-I integrons were detected only in 6.1\% $(n=4 / 66)$ of sulfisoxazole-resistant $S$. Typhimurium and in $0 \%$ of the sulfisoxazole-resistant $S$. Kentucky isolates. Three of the class-I integron positive isolates were recovered from pre-chill samples and were resistant to tetracycline-sulfisoxazole (TSu) and one was isolated from a post-chill sample and was resistant to tetracyclinestreptomycin-sulfisoxazole (TStSu). The amplicon size for both class-I integrons and bla $a_{\mathrm{CM}}$ genes was $1 \mathrm{~kb}$ (Fig. 1). There was no discernible effect of the chilling step and antibiotic resistance profile on the presence of bla $a_{\mathrm{CMY}}$ genes and class-I integrons $(P>0.05)$.

Zhao et al. (2003) reported that among the S. enterica serotype Newport isolated from humans and food animals, the bla $a_{\mathrm{CMY}}$ genes were present in all ceftiofur resistant isolates whereas $40 \%$ of the isolates possessed class-I integrons. Likewise, other studies (Chen et al., 2004; White et al., 2003, 2001; Zhao et al., 2006) found class-I integrons in a certain percentage of their tested isolates and a $100 \%$ incidence of the $b l a_{\mathrm{CMY}}$ genes, which agrees with the current study. Chen et al. (2004) indicated that $54 \%$ of Salmonella isolates tested had integrons ranging in size from 0.75 to $2.7 \mathrm{~kb}$. In contrast, the amplicon size was $1.0 \mathrm{~kb}$ for all detected class-I integrons and bla $_{\mathrm{CMY}}$ genes in our study. This might be due to the isolation of Salmonella from carcasses of a single processing plant where flocks were subjected to the same management practices. The majority (94.5\%) of sulfisoxazole resistant S. Typhimurium and S. Kentucky isolates did not possess class-I integrons, suggesting the presence of alternative resistance mechanisms for this antimicrobial.

The bla $_{\mathrm{CMY}}$ genes were detected in all ceftiofur resistant Salmonella isolates which also displayed resistance to the third generation cephalosporin, ceftriaxone. These results are consistent with other published reports on ceftiofur resistant Salmonella (Chen et al., 2004; Zhao et al., 2001, 2003, 2009) which observed this gene in all ceftiofur resistant Salmonella isolates.

The DNA sequence analysis revealed that the class-I integrons (GenBank Accession number DQ861642.1) were identical to each other and contained dihydrofolate reductase (dfrA14) and aminoglycoside adenyltransferase ( $\operatorname{adA} 1$ ) genes that encode resistance to trimethoprim, streptomycin and spectinomycin. Zhao et al. (2006; 2007) also reported these genes in class-I integrons of Salmonella recovered from human and food animals. The DNA sequence analysis of the PCR amplicon of the bla $a_{\mathrm{CMY}}$ genes revealed $99 \%$ similarity to a previously reported $b_{\mathrm{CM}}-2$ gene of $S$. Typhimurium (GenBank accession number GQ398239.1). These findings are also in agreement with the results of previous studies (Ahmed et al., 2009; Chen et al., 2004; White et al., 2001; Zhao et al., 2006, 2007) which identified these genes in Salmonella.

\subsection{Pulsed Field Gel Electrophoresis (PFGE)}

Pulsed field gel electrophoresis (PFGE) has been shown to be highly discriminative for epidemiological studies of Salmonella (White et al., 2001; Zhao et al., 2003; Zhao et al., 2006). It has also been reported that this technique could be the most discriminatory genotypic method to provide a reproducible DNA fingerprinting patterns for foodborne pathogens. Previous studies used PFGE to characterize isolates from different sources. In this study, the effect of chilling process on the PFGE patterns of Salmonella isolated from broiler carcasses was investigated. Also, PFGE was used to assess the genetic relatedness between the $S$. Typhimurium and $S$. Kentucky isolates recovered from pre- and post-chill whole broilers carcasses in a large poultry establishment.

A total of 213 PFGE banding patterns were generated from 309 S. Typhimurium and $S$. Kentucky isolated from pre- and post-chill whole broiler carcasses, indicating extensive genetic diversity among the isolates. At $60 \%$ pattern similarity index, PFGE patterns grouped into 14 clusters and these clusters showed concordance with the serotypes, isolation site, and the antibiotic resistance profile (Table 3 ). At a $100 \%$ pattern similarity index, thirty-six percent of the undistinguishable $S$. Typhimurium isolates were recovered from the same chilling step, and $26.67 \%$ had the same antibiotic resistance profile whereas, $21.80 \%$ of the undistinguishable $S$. Kentucky isolates were isolated from the same chilling step and $12 \%$ had the same antibiotic profile (data not shown). These results indicate that chilling step and antibiotic resistance profile had an effect on the recovery of certain Salmonella PFGE patterns from processed carcasses.

In April 2005, PFGE revealed 25 banding patterns from 34 isolates (one $S$. Typhimurium and 33 S. Kentucky). At a 100\% pattern similarity index, PFGE patterns grouped into six clusters. Cluster 1 contained two isolates; all were $S$. Kentucky isolated from postchill, and they were resistant to TAAmCCe. Cluster 2 contained two $S$. Kentucky isolated from pre-chill, one of them was resistant to TAAmCCe, and the other was resistant to TAAmCCeSt. Cluster 3 contained two $S$. Kentucky isolated from post-chill, both were 
Table 3

PFGE patterns and clusters for the $S$. Typhimurium and $S$. Kentucky isolates.

\begin{tabular}{|c|c|c|c|c|c|}
\hline \multirow[t]{2}{*}{ Clusters $^{\mathrm{a}}$} & \multirow{2}{*}{$\begin{array}{l}\text { \#of isolates } \\
\text { and serotype }\end{array}$} & \multirow{2}{*}{$\begin{array}{l}\text { \#of isolates } \\
\text { and isolation } \\
\text { site }\end{array}$} & \multirow[t]{2}{*}{ Clusters $^{\mathrm{b}}$} & \multirow{2}{*}{$\begin{array}{l}\text { S. Typhimurium } \\
\text { \#of isolates } \\
\text { and Chiller } \\
\text { site }\end{array}$} & \multirow{2}{*}{$\begin{array}{l}\text { S. Kentucky } \\
\text { \#of isolates } \\
\text { and Chiller } \\
\text { site }\end{array}$} \\
\hline & & & & & \\
\hline \multirow[t]{4}{*}{ A } & $4 S$. & $3 \operatorname{Pr}$ & 1 & $2 \mathrm{Pr}$ & 2 Po \\
\hline & Typhimurium & $1 \mathrm{Po}$ & & & \\
\hline & $2 S$. Kentucky & $2 \operatorname{Pr}$ & 2 & $1 \mathrm{Pr}$ & $1 \mathrm{Pr}$ \\
\hline & & & & $1 \mathrm{Po}$ & 1 Po \\
\hline \multirow[t]{6}{*}{ B } & 9 S. Kentucky & $6 \mathrm{Pr}$ & 3 & 2 Po & $1 \mathrm{Po}$ \\
\hline & & 3 Po & & & $1 \mathrm{Pr}$ \\
\hline & 47 S. Kentucky & $22 \mathrm{Pr}$ & 4 & 2 Po & 2 Po \\
\hline & & $25 \mathrm{Po}$ & & & \\
\hline & 30 S. Kentucky & $9 \mathrm{Pr}$ & 5 & $2 \mathrm{Pr}$ & 2 Po \\
\hline & & 21 Po & & & \\
\hline \multirow[t]{3}{*}{ C } & 47 S. Kentucky & $30 \mathrm{Pr}$ & 6 & $2 \mathrm{Pr}$ & $1 \mathrm{Pr}$ \\
\hline & & 17 Po & & & $1 \mathrm{Po}$ \\
\hline & 2 S. Kentucky & 2 Po & 7 & $2 \mathrm{Pr}$ & 1 Po \\
\hline $\mathrm{D}$ & 4 S. Kentucky & 4 Po & 8 & 2 Po & $2 \mathrm{Pr}$ \\
\hline \multirow[t]{3}{*}{$\mathrm{E}$} & $1 S$ & 1 Po & 9 & 3 Po & $2 \operatorname{Pr}$ \\
\hline & Typhimurium & & & & \\
\hline & 2 S. Kentucky & $2 \operatorname{Pr}$ & 10 & $3 \mathrm{Pr}$ & $2 \operatorname{Pr}$ \\
\hline \multirow[t]{4}{*}{$\mathrm{F}$} & $23 S$. & $13 \mathrm{Pr}$ & 11 & $3 \mathrm{Pr}$ & $1 \mathrm{Pr}$ \\
\hline & Typhimurium & 10 Po & & & 1 Po \\
\hline & 5 S. Kentucky & $1 \mathrm{Pr}$ & 12 & $4 \mathrm{Pr}$ & $2 \mathrm{Pr}$ \\
\hline & & 4 Po & & & \\
\hline \multirow[t]{2}{*}{ G } & 20 S. Kentucky & $10 \mathrm{Pr}$ & 13 & & 1 Po \\
\hline & & 10 Po & & & $1 \mathrm{Pr}$ \\
\hline \multirow[t]{2}{*}{$\mathrm{H}$} & 15 S. Kentucky & $3 \operatorname{Pr}$ & 14 & & 1 Po \\
\hline & & 12 Po & & & $1 \mathrm{Pr}$ \\
\hline I & $5 S$. & $1 \mathrm{Pr}$ & 15 & & $1 \mathrm{Po}$ \\
\hline & Typhimurium & 4 Po & & & $1 \mathrm{Pr}$ \\
\hline & $2 S$. Kentucky & $1 \mathrm{Pr}$ & 16 & & 1 Po \\
\hline & & 1 Po & & & $1 \mathrm{Pr}$ \\
\hline $\mathrm{J}$ & $30 \mathrm{~S}$ & $18 \mathrm{Pr}$ & 17 & & 2 Po \\
\hline & Typhimuium & 12 Po & & & \\
\hline & $1 \mathrm{~S}$. Kentucky & 1 Po & 18 & & 2 Po \\
\hline $\mathrm{K}$ & $12 S$. & $9 \mathrm{Pr}$ & 19 & & $2 \mathrm{Pr}$ \\
\hline & Typhimurium & 3 Po & & & \\
\hline & $10 \mathrm{~S}$. Kentucky & $3 \mathrm{Pr}$ & 20 & & 1 Po \\
\hline & & 7 Po & & & $1 \mathrm{Pr}$ \\
\hline $\mathrm{L}$ & 7 S. Kentucky & 7 Po & 21 & & $1 \mathrm{Pr}$ \\
\hline & & & & & $1 \mathrm{Po}$ \\
\hline M & $21 S$. Kentucky & $9 \operatorname{Pr}$ & 22 & & 3 Po \\
\hline & & 12 Po & & & \\
\hline $\mathrm{N}$ & $10 \mathrm{~S}$. Kentucky & $4 \mathrm{Pr}$ & 23 & & 2 Po \\
\hline & & 6 Po & & & $1 \mathrm{Pr}$ \\
\hline & & & 24 & & 3 Po \\
\hline & & & 25 & & $2 \mathrm{Pr}$ \\
\hline & & & & & $1 \mathrm{Po}$ \\
\hline & & & 26 & & $3 \mathrm{Po}$ \\
\hline & & & 27 & & $3 \mathrm{Pr}$ \\
\hline & & & 28 & & 3 Po \\
\hline & & & 29 & & 3 Po \\
\hline & & & 30 & & 3 Po \\
\hline & & & 31 & & $1 \mathrm{Pr}$ \\
\hline & & & & & 2 Po \\
\hline & & & 32 & & $4 \mathrm{Pr}$ \\
\hline & & & 33 & & $3 \mathrm{Pr}$ \\
\hline & & & & & 2 Po \\
\hline & & & 34 & & $3 \mathrm{Pr}$ \\
\hline & & & & & 2 Po \\
\hline & & & 35 & & 6 Po \\
\hline & & & 36 & & $5 \mathrm{Po}$ \\
\hline & & & & & $1 \mathrm{Pr}$ \\
\hline & & & 37 & & $2 \mathrm{Pr}$ \\
\hline & & & & & $4 \mathrm{Po}$ \\
\hline & & & 38 & & $4 \mathrm{Pr}$ \\
\hline & & & & & 3 Po \\
\hline
\end{tabular}

Pr, pre-chill; Po, post-chill.

a PFGE clusters at $60 \%$ similarity index.

b PFGE clusters at $100 \%$ similarity index. resistant to TAAmCCeSt. Cluster 4 contained five S. Kentucky isolated from post-chill two were resistant to TAAmCCeSt, two were resistant TAAmCCe, and one was resistant to TAAmCCeSuK. Cluster 5 contained two $S$. Kentucky isolated from post-chill, one was resistant to TAAmCCe, and the other was resistant to TAAmCCeSt. Cluster 6 contained two $S$. Kentucky isolated from post-chill; both were resistant to TAAmCCe (Fig. 2). We also found similar trends for the rest of the tested months.

PFGE and antimicrobial resistance profiles revealed a high degree of clonal diversity among the isolates. Previous studies (Nde et al., 2006; White et al., 2001, 2003; Xia et al., 2009; Zhao et al., 2006, 2007) indicated diversity among PFGE patterns, and concordance among PFGE clusters, serotypes and antibiotic resistance profiles. Our results are consistent with the results of these studies which observed correlation between the PFGE patterns, serotypes and antibiotic resistance profiles. This indicates that the emergence of resistance observed in our study is not due to a recent spread of a single clone. Some patterns (for example pattern 55; Fig. 3) were seen in both pre- and post-chill isolates, whereas others were seen only in post-chill isolates, indicating that these isolates were picked up during the chilling process. These results suggest that the chilling process is a crucial point of Salmonella contamination and cross- contamination in the chicken processing procedure.

Similar PFGE and antibiotic resistant patterns were found repeatedly over a few months. For example, PFGE pattern 11 and antibiotic resistant pattern TAAmCCe; PFGE pattern 55 and antibiotic resistance TAAmCCeSt were observed in pre- and post- chill carcasses recovered in December 2004 and April 2005 (Fig. 3). Similar trends were also observed for the months of February, March, and April 2005. This might be due to the ability of certain Salmonella strains to survive and persist in carcasses during the chilling process.

\subsection{Detection of virulence genes}

Salmonella isolates possessing invA genes are capable of invasion of cultured epithelial cells. The $p a g C$ gene is also a chromosomal virulence gene that contributes to the survival of Salmonella within the macrophages and is essential for Salmonella virulence (Fields et al., 1986). The $s p v C$ is another virulence factor of Salmonella; however, unlike the invA and pagC genes, the $\operatorname{spvC}$ gene is located on a plasmid and contributes to virulence in $S$. Typhimurium (Gulig and Curtiss, 1988; Gulig et al., 1993). The spv genes promote prolific growth of the Salmonella species in the reticuloendothelial tissues of the host. However, the full biological function of the gene products associated with $s p v A,-B,-C$, and $-D$ genes is not clear yet. $S p v$ gene expression is induced when bacteria are in the stationary phase or under stress conditions, such as iron scarcity or low $\mathrm{pH}$ (Valone et al., 1993). Expression of these genes is also induced within the first hour of internalization by macrophages, intestinal epithelial cells, and hepatocytes (Chen et al., 1996; Fierer et al., 1993). Nutrient deprivation associated with the intracellular environment may also induce spv expression (Wilson et al., 1997).

All isolates in this study contained invA and pagC but only $1.3 \%$ contained $s p v C$ (all of them were $S$. Typhimurium). The sizes of the amplicons for invA, pagC and spvC genes were 284 bp (Fig. 4), 318 bp (Fig. 5), and 400 bp (Fig. 6), respectively. There was no effect $(P>0.05)$ of the chilling step and antibiotic resistance profile on the presence of the three tested virulence factors. These results indicate that Salmonella isolates can possess virulence factors that give them the potential to cause salmonellosis irrespective of chilling treatment. In this regard, our data were similar to what was reported by other investigators where chilling failed to affect the invA and pagC 


\begin{tabular}{|l|l|lll}
\hline & \\
\hline &
\end{tabular}

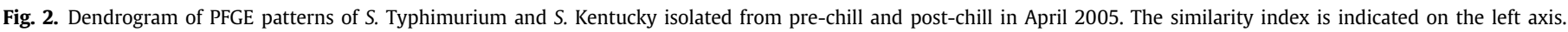

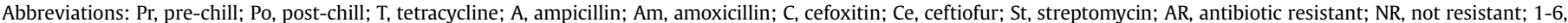
clusters at $100 \%$ similarity index.

virulence genes (Olah et al., 2005; Nolan et al., 1995; Swamy et al., 1996).

Olah et al. (2005) studied the prevalence of some virulence characteristics associated with Salmonella isolates recovered from processed turkey carcasses in the Midwestern region of the U. S. and found that all isolates were positive for the presence of the inv $\mathrm{A}$ and pagC but were negative for $s p v C$, whereas, in our study, $1.3 \%$ of the isolates were positive for $s p v C$, and all were $S$. Typhimurium. Their findings may be related to the Salmonella serotypes recovered in their study. Other researchers stated that $s p v C$ gene is frequently found in $S$. Typhimurium strains within the virulence plasmid, and this finding agrees with our results (Gulig et al., 1993; Maddox and Fales, 1991). Swamy et al. (1996) added that spvC might have the ability for chromosomal integration. Further research is needed to determine the factors that affect the presence and expression of $s p v C$ gene in $S$. Typhimurium recovered from pre- and post-chill whole broiler carcasses.

Nolan et al. (1995) studied three genes (invA, pagC, and spvC) in 103 Salmonella isolates from animals in an attempt to determine whether these genes might be useful in diagnostic procedures. However, pagC was detected in $99 \%$ of the Salmonella tested, and invA was detected in $94.2 \%$ of the isolates. Both pagC and invA were 


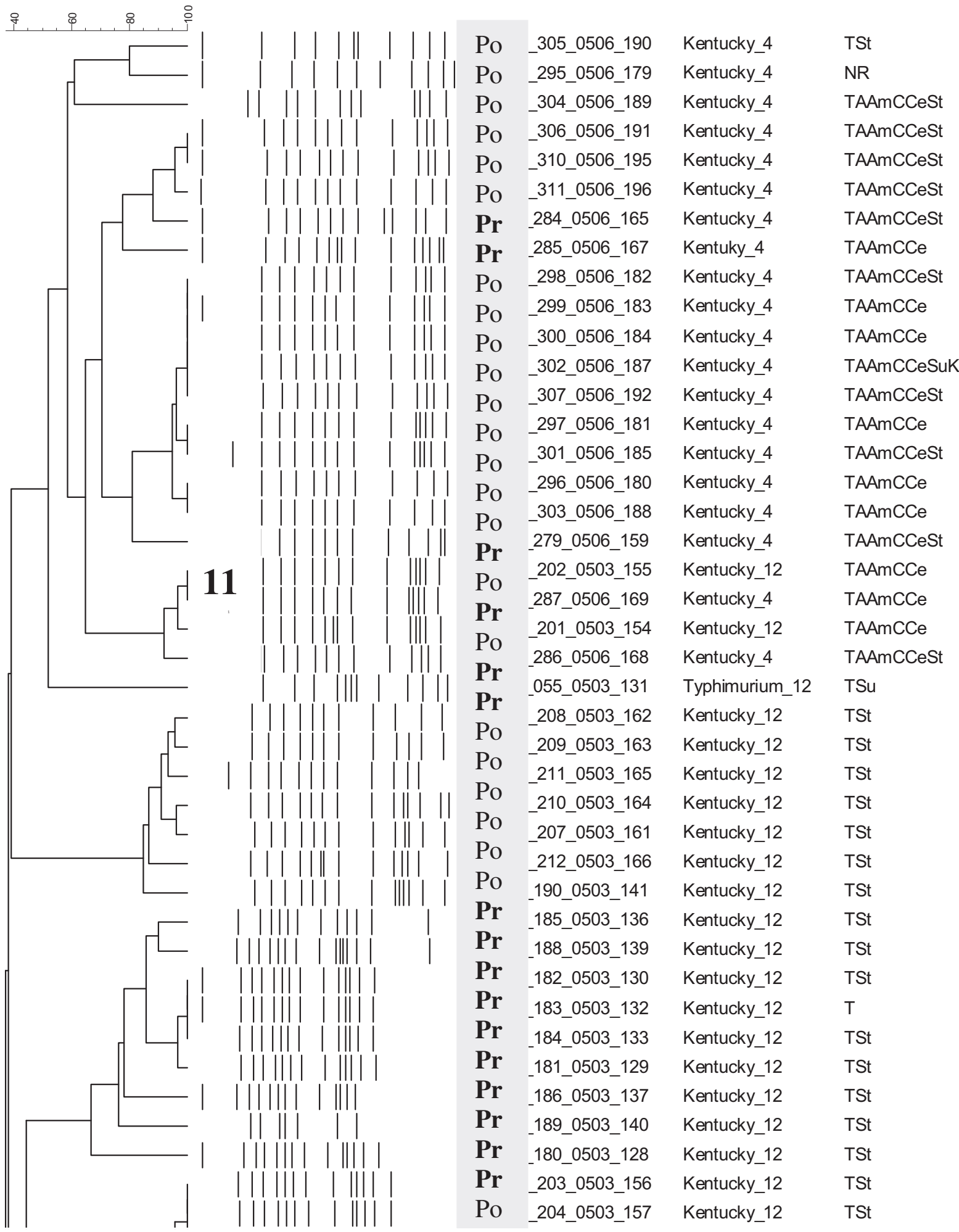



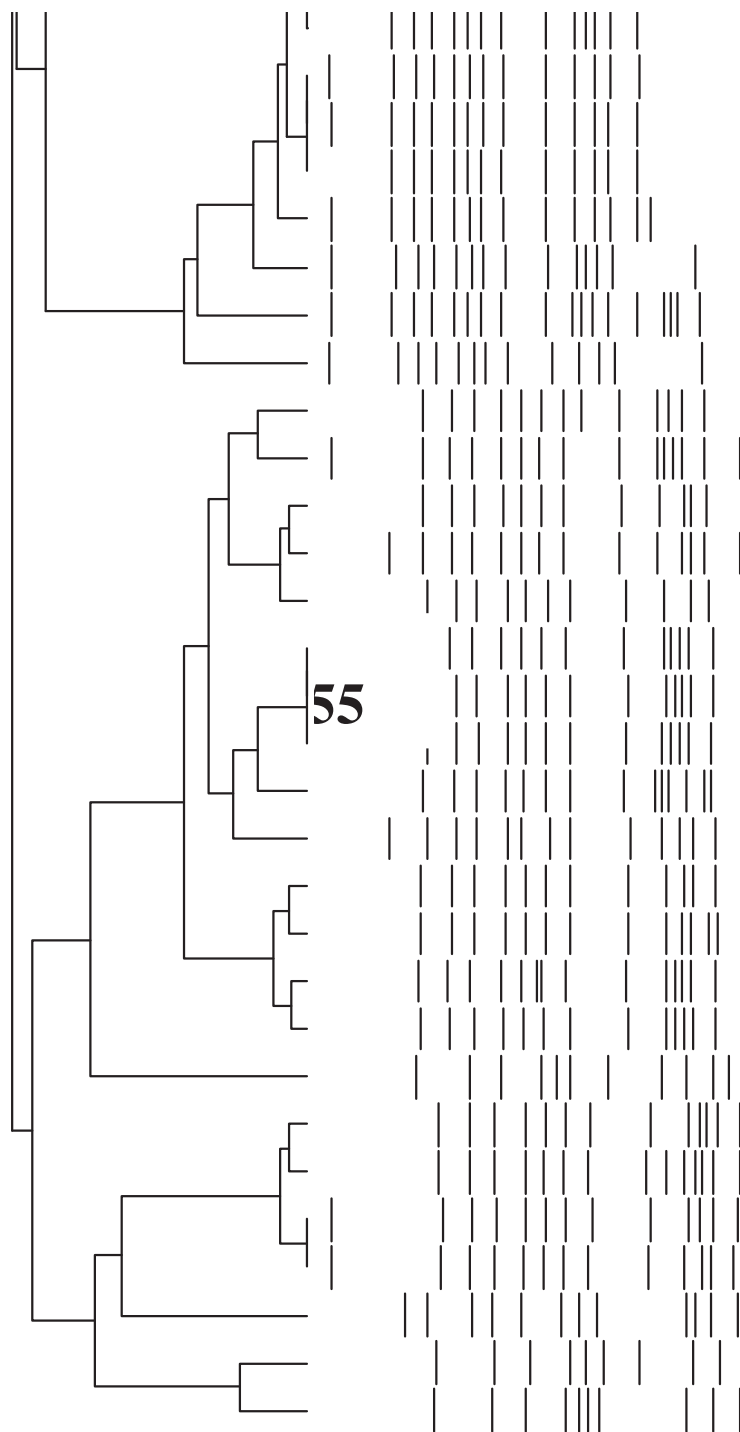

$\begin{array}{ll}\text { Po } & \text { 205_0503_158 } \\ \text { Pr } & \text { 193_0503_145 } \\ \text { Po } & \text {-196_0503_149 } \\ \text { Po } & \text {-199_0503_152 } \\ \text { Pr } & \text { 194_0503_146 } \\ \text { Pr } & \text {-192_0503_144 } \\ \text { Po } & \text {-197_0503_150 } \\ \text { Pr } & \text { 191_0503_143 } \\ \text { Pr } & \text { 292_0506_175 } \\ \text { Pr } & \text { 293_0506_176 } \\ \text { Pr } & \text { 291_0506_173 } \\ \text { Pr } & \text { 294_0506_177 } \\ \text { Pr } & \text { 289_0506_171 } \\ \text { Po } & \text {-195_0503_148 } \\ \text { Po } & \text {-200_0503_153 } \\ \text { Pr } & \text { 288_0506_170 } \\ \text { Pr } & \text { 290_0506_172 } \\ \text { Po } & \text {-198_0503_151 } \\ \text { Pr } & \text { 280_0506_160 } \\ \text { Pr } & \text { 283_0506_164 } \\ \text { Pr } & \text { 281_0506_161 } \\ \text { Pr } & \text { 282_0506_163 } \\ \text { Pr } & \text {-187_0503_138 } \\ \text { Po } & \text {-057_0503_147 } \\ \text { Po } & \text { 206_0503_160 } \\ \text { Po } & \text {-308_0506_193 } \\ \text { Po } & \text {-309_0506_194 } \\ \text { Po } & \text {-0950506_178 } \\ \text { Pr } & \text { 056_0503_134 } \\ \text { Po } & \text {-058_0503_159 }\end{array}$

Kentucky_12

Kentucky_12

Kentucky_12

Kentucky_12

Kentucky_12

Kentucky_12

Kentucky_12

Kentucky_12

Kentucky_4

Kentucky_4

Kentucky_4

Kentucky_4

Kentucky_4

Kentucky_12

Kentucky_12

Kentucky_4

Kentucky_4

Kentucky_12

Kentucky_4

Kentucky_4

Kentucky_4

Kentucky_4

Kentucky_12

Typhimurium_12

Kentucky_12

Kentucky_4

Kentucky_4

Typhimurium_4

Typhimurium_12

Typhimurium_12
TSt

TSt

$\mathrm{T}$

TSt

TSt

$\mathrm{T}$

T

T

TAAmCCeSt

AAmCCeSt

TAAmCCeSt

TAAmCCeSt

TAAmCCeSt

TAAmCCeSt

TAAmCCeSt

TAAmCCeSt

TAAmCCe

TAAmCCe

TAAmCCeSt

TAAmCCeSt

TAAmCCeSt

TAAmCCeSt

TAAmCCeStSuK

TAAmCCeSt

TSt

TAAmCCe

TAAmCCe

TAAmCCeSt

TAAmCCeSuK

NR

Fig. 3. (continued)

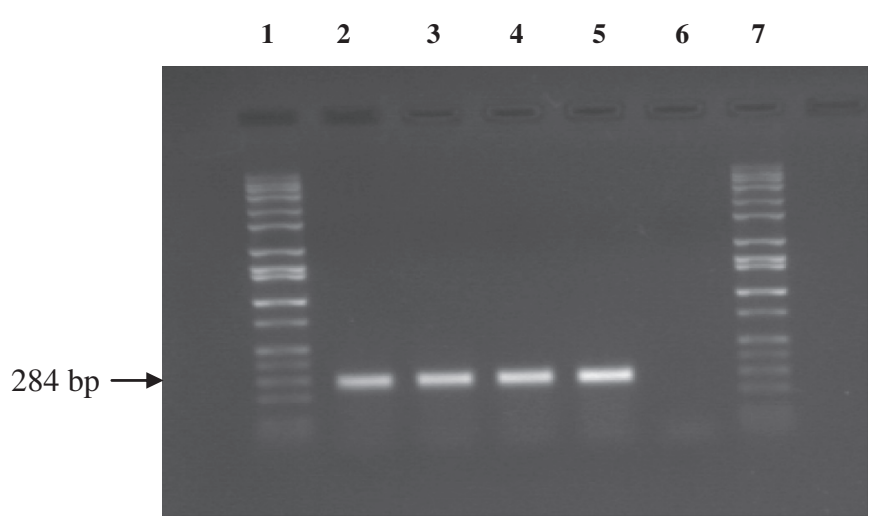

Fig. 4. PCR amplification of invA gene in selected Salmonella Typhimurium and $S$. Kentucky isolates. Lanes 1 and 7, Hi Low DNA marker (Minnesota Molecular, Minneapolis, MN); lane 5, positive control $S$. Typhimurium Lt- $2 \times 3324$; lane 6 , negative control E. coli DH5- $\alpha$; lanes 2 through 4 positive test isolates of Salmonella.

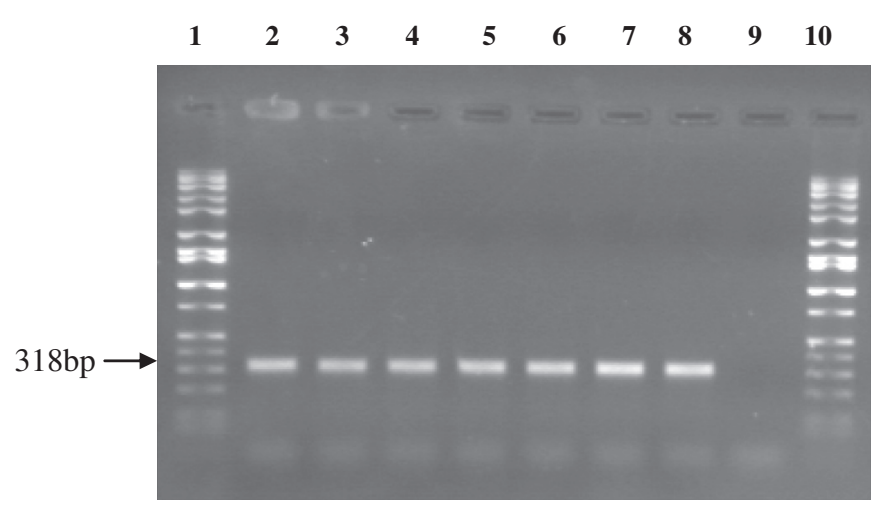

Fig. 5. PCR amplification of pagC gene in selected Salmonella Typhimurium and $S$. Kentucky. Lanes 1 and 10, Hi Low DNA marker (Minnesota Molecular, Minneapolis, MN); lane 8, positive control S. Typhimurium Lt-2X3324; lane 9, negative control E. coli DH5- $\alpha$; lanes 2 through 7 positive test isolates of Salmonella. 


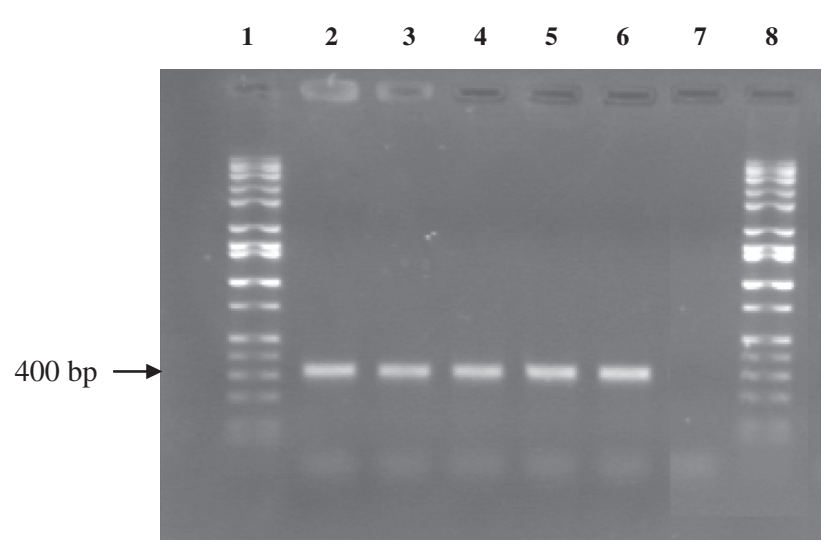

Fig. 6. PCR amplification of $s p v C$ gene in Salmonella isolates. Lanes 1 and 8 , Hi Low DNA marker (Minnesota Molecular, Minneapolis, MN); lane 6, positive control $S$. Typhimurium Lt-2x3324; lane 7, negative control E. coli DH5- $\alpha$; lanes 2 through 5 positive test isolates of Salmonella.

detected with a significantly higher frequency than $s p v C$ in isolates from chickens and swine, but no significant difference in detection of these three genes occurred when bovine isolates were examined. Failure to detect any of these genes occurred in only one isolate. Isolates from apparently healthy or from clinically ill chickens and swine could not be distinguished by detecting these three genes. The genes were not detected in the non Salmonella strains tested. The $s p v C$ positive isolates percentage was $75.7 \%$ whereas in our study the percentage was very low and that may be related to its location on the virulence plasmids which may not always be present (Gulig et al., 1993; Van der Valden et al., 1998).

\subsection{Aerobactin and colicin assays}

Production of aerobactin and colicin was not affected by chilling but was significantly different among isolates of $S$. Typhimurium and S. Kentucky. Overall, 95 (30.74\%) of the isolates were aerobactin producers, and $127(41.1 \%)$ were colicin producers. Most of the aerobactin $66(21.36 \%)$ and colicin 119 (38.5\%) producers were $S$. Kentucky. Among the 66 (21.36\%) aerobactin producers of $S$. Kentucky, 32 (10.36\%) were from pre-chill and 34 (11.0\%) were from post-chill. Sixteen (5.18\%) of pre- and 13 (4.2\%) of post-chill $S$. Typhimurium isolates were aerobactin producers. There was no significant difference $(P>0.05)$ in the production of aerobactin between pre- and post-chill $S$. Typhimurium and $S$. Kentucky isolates. These results indicated that chilling had no effect on the production of aerobactin and colicins of Salmonella. However, there was a significant difference $(P<0.05)$ in the production of aerobactin between $S$. Typhimurium and $S$. Kentucky. Among the 119 (38.5\%) colicin producers, 64 (20.71\%) S. Kentucky isolates were from pre-chill and 55 (17.8\%) were from post-chill. Five (1.62\%) preand $3(0.97 \%)$ post-chill $S$. Typhimurium isolates were colicin producers. Also, there was no difference $(P>0.05)$ in the production of colicin between pre-chill and post-chill $S$. Typhimurium and $S$. Kentucky isolates. However, there was a significant difference $(P<0.05)$ in the production of colicin between $S$. Typhimurium and $S$. Kentucky.

The production of aerobactin in Salmonella virulence is related to scarce amount of iron (Doyle et al., 2001). In contrast, colicin is produced to destroy other microorganisms, thus allowing the producing organism a survival advantage (Lazdunski et al., 1998). These results are consistent with the results of previous studies that showed certain percentages of bacteria can be aerobactin or colicin producers (Cercenado et al., 1986; Martinez et al., 1987; Olah et al., 2005; Suarez et al., 1995; Vidotto et al., 1990).
Though the incidence of infection with $S$. Kentucky is quite low compared to S. Typhimurium (Finstad et al., 2012), our results revealed higher percentage of aerobactin and colicin producing $S$. Kentucky than $S$. Typhimurium. We also observed that there was no significance difference in the prevalence of invA and pagC genes between $S$. Kentucky and $S$. Typhimurium. These results suggest that other virulence factors may play significant role in the pathogenesis of $S$. Typhimurium. Further research is needed to confirm this explanation.

\section{Conclusions}

All ceftiofur resistant Salmonella isolates were positive for bla $_{\mathrm{CMY}}$ genes, only $6.1 \%$ of sulfisoxazole-resistant isolates contained class-I integrons suggesting a weak association between sulfisoxazole-resistance and the presence of class-I integrons in this study. The PFGE analysis revealed the presence of genetically diverse populations among Salmonella serotypes. The results of this study also indicate that chilling impacted the recovery of particular Salmonella clonal groups but had no bearing on the prevalence of class-I integrons, bla $a_{\mathrm{CMY}}$ genes, and virulence factors (invA, pagC and $s p v C$ ). Further, our PFGE results confirm that the chilling process is a crucial point of Salmonella contamination and cross- contamination in the chicken processing procedure. This study will benefit public health by assisting the poultry industry in adapting preventive measures necessary to improve the microbiological safety of poultry and poultry products.

\section{Acknowledgments}

The research was supported by the USDA Evans-Allen. We are grateful to Ms. Sharon Friedman Microbiologist, CVM, FDA, Laurel, Maryland, Dr. M. Santin and Ms. C. Lam, EMFSL Beltsville, Maryland for technical assistance. We are also indebted to Dr. Anthony Nyame and his students Ms. Nelum Dorabawila and Ms. Msano Mandalasi, Department of Natural Sciences, University of Maryland Eastern Shore to allowing us to use their Camera, Dr. Catherine Logue and Ms. Julie Sherwood, North Dakota State University for providing us positive and negative control strains used in the bioassays. We are grateful to Drs. Thomas Oscar and Jeff Karns, USDA, ARS, and Ms. Chanelle White, Ms. Rizwana Tasmin, Drs. Jürgen Schwarz and Fawzy Hashem, Food Science and Technology Ph.D. Program, University of Maryland Eastern Shore for their helpful suggestions.

\section{References}

Ahmed, A.M., Shimabukuro, H., Shimamoto, T., 2009. Isolation and molecular characterization of multidrug-resistant strains of Escherichia coli and Salmonella form retail chicken meat in Japan. J. Food Sci. 74, M405-M410.

Arestrup, F.M., Seyfarth, A.M., Emborg, H.N., Pedersen, K., Hendriksen, R.S., Bager, F., 2001. Effect of abolishment of the use of antimicrobial resistance in fecal Enterococci from food animals in Denmark. Antimicrob. Agents Chemother. 45, 2054-2059.

Beers, H.M., 2003. The Merck Manual of Medical Information, second home ed. Merck, Whitehouse Station, NJ.

Beery, J.T., Hugdahl, M.B., Doyle, M.P., 1988. Colonization of gastrointestinal tract of chicks by Campylobacter jejuni. Appl. Environ. Microbiol. 54, 2365-2370.

Bradford, P.A., Petersen, P.J., Fingerman, I.M., White, D.G., 1999. Characterization of expanded-spectrum cephalosporin resistance in E. coli isolates associated with bovine calf diarrheal disease. Antimicrob. Agents Chemother. 44, 607-610.

Brown, H.J., Stokes, H.W., Hall, R.M., 1996. The integrons In0, In2, and In5 are defective transposon derivates. J. Bacteriol. 178, 4429-4433.

Centers for Disease Control and Prevention (CDC), 2006. Salmonella Surveillance: Annual Summary, 2005. Atlanta. GA.

Cercenado, E., Baquero, F., Deigado-lribarren, A., Martinez, J.L., 1986. Epidemiology of aerobactin production in Enterobacteriaceae. Ann. Inst. Pasteur Mic 137, 297-303.

Chen, C.Y., Eckmann, L., Libby, S.J., Fang, F.C., Okamoto, S., Kagnoff, M.F., Fierer, J., Guiney, D.G., 1996. Expression of Salmonella Typhimurium rpoS and rpoS 
dependent genes in the intracellular environment of eukaryotic cells. Infect. Immun. 64, 4739-4743.

Chen, S., Zhao, S., White, D.G., Schroeder, C.M., Lu, R., Yang, H., McDermott, P.F. Ayers, S., Meng, J., 2004. Characterization of multiple-antimicrobial-resistant Salmonella serovars isolated from retail meats. Appl. Environ. Microbiol. 70, $1-7$.

Doyle, P.M., Beuchat, R.L., Montville, J.T., 2001. Food Microbiology, Fundamentals and Frontiers, second ed., pp. 141-178.

Fields, P. Swanson, RV. Haidaris, C. ., Heffron, F, 1986. Mutants of Salmonella Typhimurium that cannot survive within the macrophage are avirulent. Proc. Natl. Acad. Sci. 83, 5189-5193.

Fierer, J., Eckmann, L., Fang, F., Pfeifer, C., Finlay, B.B., Guiney, D., 1993. Expression of the Salmonella virulence plasmid gene spvB in cultured macrophages and non phagocytic cells. Infect. Immun. 61, 5231-5236.

Finstad, S., O’Bryan, C.A., Marcy, J.A., Crandall, P.G., Ricke, S.C., 2012. Salmonella and broiler processing in the United States: relationship to foodborne salmonellosis. Food Res. Int. 45, 789-794.

Fluit, A.C., Schmitz, F.J., 2004. Resistance integrons and super-integrons. Clin. Microbiol. Infect. 10, 272-288.

Fredericq, P., 1956. Reserchers sur la frequence des souches transuctrices des propietes colicinogenes. Roy. Soc. Biol. 150, 1036-1039.

Galan, J.E., Curtiss III, R., 1989. Cloning and molecular characterization of genes whose products allow Salmonella Typhimurium to penetrate tissue culture cells. Proc. Natl. Acad. Sci. U.S.A. 86, 6383-6387.

Gulig, P.A., Curtiss III, R., 1988. Cloning and transposon insertion mutagenesis of virulence genes of the 100-kilobase plasmid of Salmonella Typhimurium. Infect. Immun. 56, 3262-3271.

Gulig, P.A., Danbara, H., Guiney, D.G., Lax, A.J., Norel, F., Rhen, M., 1993. Molecular analysis of $s p v$ virulence genes of the Salmonella virulence plasmids. Mol. Microbiol. 7, 825-830.

Helms, M.P., Vastrup, P., Gerner-Smidt, P., Molbak, K., 2002. Excess mortality associated with antimicrobial drug-resistant Salmonella Typhimurium. Emerg. Infect. Dis. 8, 490-495.

Izat, A.L., Driggers, C.D., Colberg, M., Reiber, M.A., Adam, M.H., 1989. Comparison of the DNA Probe to culture methods for the detection of Salmonella on poultry carcasses and processing waters. J. Food Prot. 52, 564-570.

Lazdunski, C.J., Bouveret, E. Rigal, A., Journet, L., Lloubes, R., Benedetti, H., 1998 Colicin import into Escherichia coli cells- minireview. J. Bacteriol. 180, 4993 5002.

Logue, C.M., Sherwood, J.S., Olah, P.A., Elijah, L.M., Dockter, M.R., 2003. The incidence of antimicrobial-resistant Salmonella spp. on freshly processed poultry from US Midwestern processing plants. J. Appl. Microbiol. 94, 16-24.

Maddox, C.W., Fales, W.H., 1991. Use of a Salmonella Typhimurium derived virulence probe in the detection of Salmonella spp. and in the characterization of S. cholerae-suis virulence plasmids. J. Vet. Diagn. Invest. 3, 218-222.

Martinez, J.L., Cercenado, E., Rodriguez-Creixems, M., Vicente-Perez, M.F., DelgadoIribarren, A., Baquero, F., 1987. Resistance to beta-lactam/clavulanate. Lancet ii, 1473.

Mead, P.S., Slutsker, L., Dietz, V., McCaig, L.F., Bresee, J.S., Shapiro, C., Griffin, P.M. Tauxe, R.V., 1999. Food-related illnesses and death in the United States. Emerg. Infect. Dis. 5, 607-625.

Nde, C.W., Sherwood, J.S., Doetkott, C., Logue, C.M., 2006. Prevalence and molecular profiles of Salmonella collected at a commercial turkey processing plant. J. Food Prot. 69, 1794-1801.

Nolan, L.K., Giddings, C.W., Brown, J., 1995. The distribution of invA, pagC, and spvC genes among Salmonella isolates from animals. Vet. Res. Commun. 19, 167-177.

Noorwood, D.E., Gilmour, A., 2000. The growth and resistance to sodium hypochlorite of Listeria monocytogenes in a steady-state multispecies biofilm. J. Appl. Microbiol. 88, 512-520.

Olah, A.P., Sherwood, S.J., Logue, M.C., 2005. Molecular analysis of Salmonella isolates recovered from processed turkey carcasses. J. Food Prot. 68, 845-849.

Parveen, S., Taabodi, M., Schwarz, G.J., Oscar, P.T., Harter-Dennis, J., White, G.D., 2007. Prevalence and antimicrobial resistance of Salmonella recovered from processed poultry. J. Food Prot. 70, 2466-2472.

Pulkkinen, W.S., Miller, S.I., 1991. A Salmonella Typhimurium virulence protein is similar to a Yersinia enterocolitica invasion protein and a bacteriophage lambda outer membrane protein. J. Bacteriol. 173, 86-93.
Rahn, K., De Grandis, S.A., Clarke, R.C., McEwen, S.A., Galan, J.E., Ginocchio, C., Curtiss III, R. Gyles, C.L., 1992. Amplification of an invA gene sequence of Salmonella Typhimurium by polymerase chain reaction as a specific method of detection of Salmonella. Mol. Cell. Probes 6, 271-279.

Scallan, E., Hoekstra, R.M., Angulo, F.J., Tauxe, R.V., Widdowson, M.A., Roy, S.L., Jones, J.L., Griffin, P.M., 2011. Foodborne illness acquired in the United Statesmajor pathogens. Emerg. Infect. Dis. 17, 7-15.

Suarez, S., Celemin, C., Zduficzyr, E., Medina, E., Williams, P.H., 1995. Aerobactin production by enterotoxigenic Escherichia coli of porcine intestine. Vet. Microbiol. 47, 229-233.

Suzuki, S., Komase, K., Matsui, H., Abe, A., Kawahara, K., Tamura, Y., Kijima, M., Danbara, H., Nakamura, M., Sato, S., 1994. Virulence region of plasmid pNL2001 of Salmonella Enteritidis. Microbiology 140, 1307-1318.

Swamy, S.C., Barnhart, H.M., Lee, M.D., Dreesen, D.W., 1996. Virulence determinants invA and $s p v C$ in salmonellae isolated from poultry products, wastewater, and human sources. Appl. Environ. Microbiol. 62, 3768-3771.

Valone, S.E., Chikami, G.K., Miller, V.L., 1993. Stress induction of the virulence proteins (SpvA, -B, and -C) from native plasmid pSDL2 of Salmonella Dublin. Infect. Immun. 61, 705-713.

Van der Valden, A.W.M., Baulmer, A.J., Tsolis, R.M., Heffron, F., 1998. Multiple fimbrial adhesions are required for full virulence of Salmonella Typhimurium in mice. Infect. Immun. 66, 2803-2808.

Vidotto, M.C., Muller, E.E., Freitas, J.C., Alfieri, A.A., Guimaraes, I.G., Santos, D.S., 1990. Virulence factors of avian Escherichia coli. Avian Dis. 34, 531-538.

White, D.G., Zhao, S., McDermott, P.F., Ayers, S., Friedman, S., Sherwood, J., Breider-Foley, M., Nolan, L., 2003. Characterization of integron mediated antimicrobial resistance in Salmonella isolated form diseased swine. Can. J. Vet. Res. 67, 39-47.

White, D.G., Zhao, S., Sudler, R., Ayers, S., Friedman, S., Chen, S., McDermott, P.F., McDermott, S., Wagner, D.D., 2001. The isolation of antibiotic-resistant Salmonella from retail ground meats. New Engl. J. Med. 345, 1147-1154.

Wilson, J.A., Doyle, T.J., Gulig, P.A., 1997. Exponential-phase expression of spvA of the Salmonella Typhimurium virulence plasmid: induction in intracellular salts medium and intracellularly in mice and cultured mammalian cells. Microbiology 143, 3827-3839.

World Health Organization, 2000. WHO Global Principles for the Containment of Antimicrobial Resistance in Animal Intended for Food. In: WHO, Department of Communicable Disease Surveillance and Responses (accessed on 04.04.10.) https://www.who.int/emc/diseases/zoo/who_global_principles/index.htm.

Xia, X., Zhao, S., Smith, A., McEvoy, J., Meng, J., Bhagwat, A.A., 2009. Characterization of Salmonella isolates from retail foods based on serotyping, pulse field gel electrophoresis, antibiotic resistance and other phenotypic properties. Int. J. Food Microbiol. 129, 93-98.

Zhao, S., Blickenstaff, K., Glenn, A., Ayers, S.L., Friedman, S.L., Abbott, J.W. McDermott, P.F., 2009. $\beta$-Lactam resistance in Salmonella strains isolated from retail meats in the United States by the National Antimicrobial Resistance Monitoring System between 2002 and 2006. Appl. Environ. Microbiol. 75, 7624-7630.

Zhao, S., McDermott, P.F., Friedman, S., Qaiyumi, S., Abbott, J., Kiessling, C., Ayers, S., Singh, R., Hubert, S., Sofos, J., White, D.G., 2006. Characterization of antimicrobial-resistant Salmonella isolated from imported foods. J. Food Prot. 69, 500-507.

Zhao, S., Qaiyumi, S., Friedman, S., Singh, R., Foley, L., White, D.G., McDermott, P.F., Donkar, T., Bolin, C., Munro, S., Baron, E.J., Walker, R.D., 2003. Characterization of Salmonella enterica serotype Newport isolated from humans and food animals. J. Clin. Microbiol. 41, 5366-5371.

Zhao, S., McDermott, P.F., White, D.G., Qaiyumi, S., Friedman, S.L., Abbott, J.W., Glenn, A., Ayers, S.L., Post, K.W., Fales, W.H., Wilson, R.B., Reggiardo, C. Walker, R.D., 2007. Characterization of multidrug resistant Salmonella recovered from diseased animals. Vet. Microbiol. 123, 122-132.

Zhao, S., White, D.G., McDermott, P.F., Friedman, S., English, L., Ayers, S., Meng, J., Maurer, J.J., Holland, R., Walker, R.D., 2001. Identification and expression of cephamycinase bla ${ }_{\mathrm{CMY}}$ gene in Escherichia coli and Salmonella isolates form food animal and ground meat. Antimicrob. Agents Chemother. 45, 3647-3650.

Zivkovic, J., Jaksie, S., Miokovic, B., 1997. Salmonella serovars in chicken meat and chicken products in Zagleb, Croatia. Vet. Archiv. 67, 169-175. 